\title{
Development of Hybrid Baccharis Plants for Desert Landscaping
}

\author{
Anson E. Thompson \\ U.S. Department of Agriculture, Agricultural Research Service, U.S. Water Conservation Laboratory, \\ Phoenix, AZ 85040 \\ Chiwon W. Lee \\ Department of Plant Sciences, North Dakota State University, Fargo, ND 58105 \\ Ronald E. Gass \\ Mountain States Wholesale Nursery, Glendale, AZ 85067
}

Relatively little research has been expended on developing plants for use in urban desert landscapes or "xeriscapes." However, because of reduced availability and increased cost of water, water conservation needs, and concerns for our environment, increased awareness and demand for arid-adapted landscape plants have developed. An especially important need is for groundcover requiring little water and maintenance for arid and semi-arid regions with their limited water supply. These groundcovers are needed for a wide array of uses, such as residential landscape plantings, parks, golf courses, highway and street medians, industrial sites, and disturbed areas.

The genus Baccharis (Asteraceae) consists of $\approx 300$ species, mostly of American origin. Baccharis sarothroides Gray, commonly known as desert broom, is an erect, resinous, small-leaved, evergreen shrub, 1 to 3 $\mathrm{m}$ tall, and 2 to $2.5 \mathrm{~m}$ wide. Desert broom is extremely well adapted to the drought, cold, heat, and high soil salinity conditions of its native habitat in the Sonoran Desert and the surrounding arid regions at 300- to $1700-\mathrm{m}$ elevation (Kearney and Peebles, 1960). Desert broom has been recommended as a native plant useful in arid-land landscaping (Duffield and Jones, 1981; Natural Vegetation Committee, Arizona Chapter Soil Conservation Society of America, 1973; Sacamano and Jones, 1975). The species is dioecious (Fig. 1). The florets in the capitula of the pistillate plants produce a large amount of pappus, which is distributed by wind at maturity and, therefore, can create a nuisance on terraces and in pools; it also can be a potential fire hazard. This constraint has limited the acceptance of desert broom as a landscape plant. Staminate plants of desert broom, which are occasionally propagated by cuttings, are available at nurseries and are free of seed head litter.

In the 1970 s a staminate prostrate selec-

\footnotetext{
Received for publication 26 May 1995. Accepted for publication 22 Aug. 1995. The research was supported in part by the Univ. of Arizona Agricultural Expt. Station, Tucson. We especially thank Warren D. Jones and LeMoyne Hogan for their ideas, support, and encouragement. The cost of publishing this paper was defrayed in part by the payment of page charges. Under postal regulations, this paper therefore must be hereby marked advertisement solely to indicate this fact,
}

tion of the dioecious coyote bush (Baccharis pilularis Wolfe) was propagated'and sold under the name of 'Twin Peaks'. Coyote bush is native to the coastal areas of Baja, Calif., and southern California below a 1000-m elevation, where the climate is mild and more humid than inland. 'Twin Peaks' proved to be a popular landscape plant in southern California and subsequently was planted in various locations in the low and intermediate deserts (Duffield and Jones, 1981; Munz, 1974). Because only the staminate form was selected, propagated, and distributed to the general public, the production of pappus on this cultivar was not a problem. However, serious problems with plant decline were clearly evident before the mid-1970s. The problem appeared to be physiological rather than pathological, but the exact cause of the plant's decline and death was never diagnosed fully. The plant's apparent sensitivity to high temperatures and low humidity and its intolerance to over-watering in the heat of summer are thought to be the cause of its poor adaptation and performance.

In 1975, Warren D. Jones (professor of landscape architecture, Univ. of Arizona, Tucson) suggested that a desirable, arid-adapted,

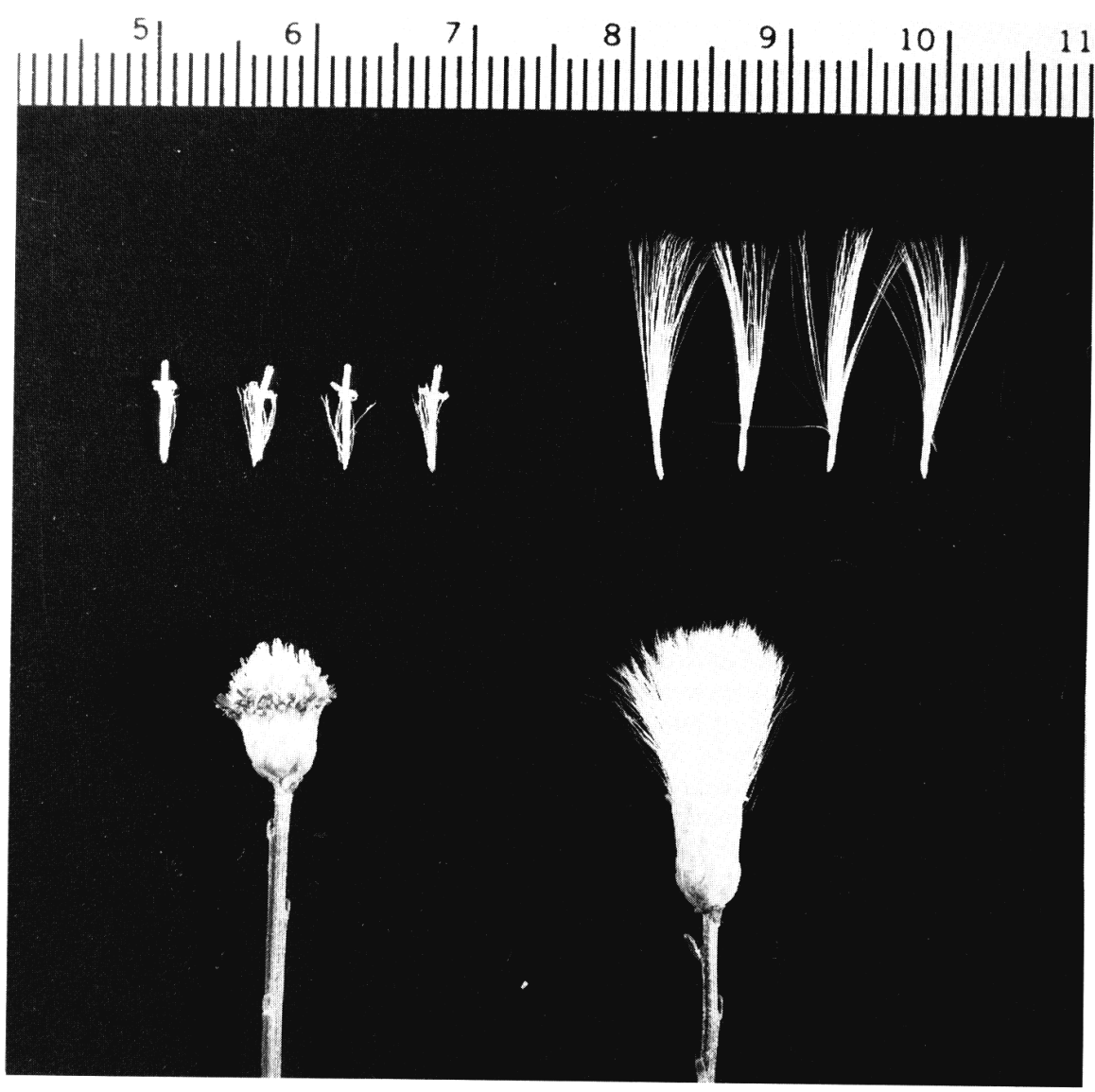

Fig. 1. (left) Excised staminate florets and (right) pistillate florets from their respective staminate and pistillate capitula of desert broom (Baccharis sarothroides Gray). Note the bristle length of the pappus on the pistillate florets. 
landscape plant might be developed through interspecific hybridization of the procumbent, nonadapted selection of coyote bush and the arid-adapted desert broom. Our paper documents the successful crossing, selection, propagation, and development of the new firstgeneration baccharis hybrid. The potential for development of new, second-generation, baccharis hybrids also is discussed.

\section{DEVELOPMENT AND CHARACTERIZATION OF FIRST-GENERATION INTERSPECIFIC HYBRIDS}

In Fall 1975, a cross was made between a pistillate plant of the native desert broom and a staminate coyote bush plant (Thompson et al., 1976). The resultant seeds were harvested and planted in seed trays in a greenhouse. Some seeds germinated within 5 days, and most completed emergence within 15 days. Most of the interspecific hybrids were detected readily in the seedling stage. The first true leaves of the hybrids were broader and shorter than those of the desert broom seedlings of similar maturity and had slight serrations along the leaf edges. Stems of hybrid seedlings also had a brownish-red pigmentation, while those of the desert broom were noticeably red. Using the differences in stem color and leaf shape and serration permitted 395 seedling plants to be classified tentatively as hybrids.

Seedling plants classified as hybrids were planted into small pots for continued growth in the greenhouse. In May 1976, a total of 373 plants were transplantedinto 3.8-liter cans and moved from the greenhouse to an outside holding area. After acclimatization for 4 months, 332 surviving plants were transplanted into a field plot at the Univ. of Arizona Campus Agricultural Center, Tucson. Plants were established at a 2-m spacing in 4-m-wide single rows and were furrow-irrigated as needed for the first 2 years. Subsequent plant growth was sustained by natural precipitation (mean annual precipitation $280 \mathrm{~mm}$ ).

Over 6 years, plants within the population were periodically examined for sex expression, seed production, drought and cold tolerance, foliage characteristics, and other growth characteristics. By the end of the third year, plants with superior form and growth habits wereidentified, and selectedplants were propagated by cuttings. At the end of the 6 years (1981), growth characteristics of all plants within the population were noted in detail. Plant width and height were recorded, and the width : height ratio was calculated to indicate the degree of procumbency or prostrate growth habit of the plants.

The hybrid plants started to flower during the second year of growth. Out of the 332 plants established in the field nursery, 324 were classified as true hybrids based on altered growth habits (Fig. 2). All hybrid plants exhibited some expression of prostrate growth habit, and all plants produced only pistillate flowers. Hybrid plants also tended to have broader and more serrated leaves than the

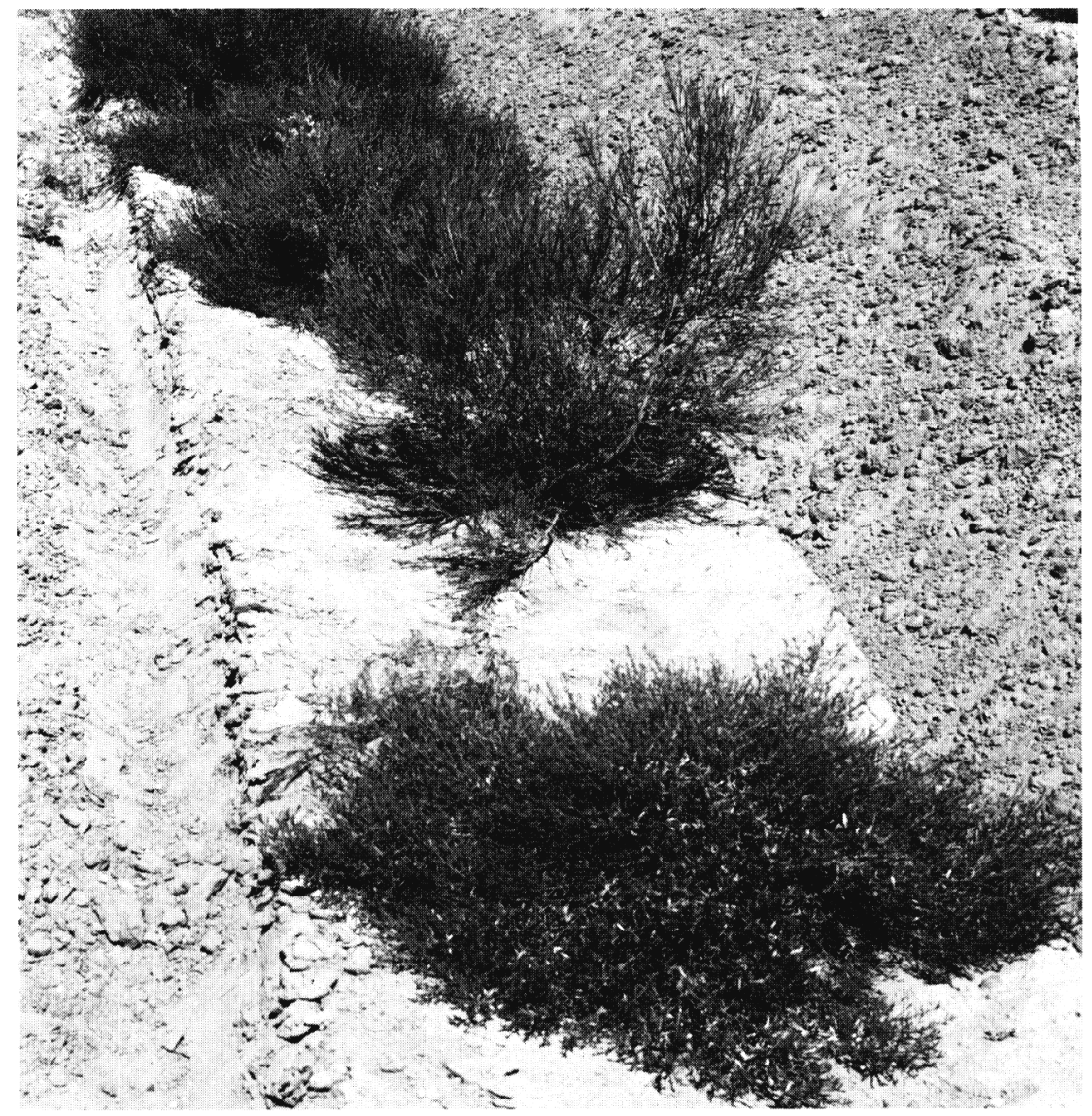

Fig. 2. Two-year-old plants of the Baccharis sarothroides $\mathrm{x}$ B. pilularis first-generation (F,) interspecific hybrid growing in a field plot at the Univ. of Arizona Campus Agricultural Center, Tucson. Note upright growth characteristics of the nonhybrid, desert broom plant, which resulted from a chance outcross at the time of hybridization.

Table 1. Comparison of growth and reproductive characteristics of Baccharis sarothroides $\mathrm{x}$ B. pilularis interspecific hybrid and two parental species.

\begin{tabular}{|c|c|c|c|}
\hline Characteristics & $\begin{array}{c}\text { Hybrid } \\
\text { (B. sarothroides } \\
\times \text { B. pilularis) } \\
(\mathrm{n}=301)\end{array}$ & $\begin{array}{l}\text { Pistillate parent } \\
\text { (B. pilularis }) \\
(\mathrm{n}=8)\end{array}$ & $\begin{array}{c}\text { Staminate parent } \\
(\text { B. pilularis })\end{array}$ \\
\hline Sex expression & Pistillate & Dioecious & Dioecious $^{2}$ \\
\hline Pappus production & Moderate & Heavy & --- \\
\hline Pistillate flower/capitulum & $30.7 \pm 4.8^{y}$ & $44.1 \pm 3.0^{y}$ & --- \\
\hline Capillary bristles/pistil & $47.6 \pm 5.9$ & $53.2 \pm 11.3$ & --- \\
\hline Bristle length (mm) & $8.8 \pm 1.1$ & $11.7 \pm 1.7$ & --- \\
\hline \multicolumn{4}{|l|}{ Seed size } \\
\hline Length $(\mathrm{mm})$ & $1.6 \pm 0.2$ & $1.9 \pm 0.2$ & --- \\
\hline Weight 100 seeds (mg) & $12.6 \pm 1.1$ & $25.8 \pm 1.5$ & --- \\
\hline Leaf shape & Oblong & Linear & Obovate \\
\hline Width (mm) & $4-5$ & $2-2.5$ & $5-10$ \\
\hline Length (mm) & $15-20$ & $20-40$ & $10-20$ \\
\hline Serration & Variable & None & Serrated \\
\hline Growth habit & $\begin{array}{l}\text { Procumbent to } \\
\text { semiprocumbent }\end{array}$ & Erect & Procumbent \\
\hline \multicolumn{4}{|l|}{ Plant width } \\
\hline Range (cm) & $152-409$ & $193-361$ & --- \\
\hline Mean $(\mathrm{cm})$ & $256 \pm 43$ & $294 \pm 61$ & --- \\
\hline \multicolumn{4}{|l|}{ Plant height } \\
\hline Range (cm) & $66-220$ & $180-350$ & --- \\
\hline Mean $(\mathrm{cm})$ & $128 \pm 27$ & $241 \pm 64$ & --- \\
\hline \multicolumn{4}{|l|}{ Plant width/height } \\
\hline Range & $1.4-3.3$ & $1.0-1.6$ & --- \\
\hline Mean & $2.0 \pm 0.3$ & $1.2 \pm 0.2$ & --- \\
\hline Amount of leaf resins & Moderate & Heavy & None \\
\hline Drought tolerance & High & High & Low \\
\hline Cold tolerance & High & High & Low \\
\hline
\end{tabular}

${ }^{2}$ Species is dioecious flowering; cultivated form is an asexually propagated staminate selection that produces only staminate flowers.

${ }^{y}$ All values are expressed as mean $(\overline{\mathrm{X}}) \pm \mathrm{SD}$. 
desert broom parent. A total of eight plants (four staminate and four pistillate), whichgrew upright and had leaf characteristics of the desert broom parent, were identified and classified as additional outcross plants. These plants were not removed from the planting but served as control plants for making comparisons with the hybrids. Of the 324 hybrids, 23 plants succumbed to root disease (pathogen not identified) during the third and fourth year, thus reducing the total population to 301 healthy plants at the end of the sixth year of growth.

Growth andreproductive characteristics of the Baccharis sarothroides $\mathrm{x}$ B. pilularis interspecific hybrid and the two parental species are contrasted in Table 1. Interestingly, the cross between the two dioecious species produced hybrid plants with capitula containing only pistillate flowers. Obviously, some type of maternal or cytoplasmic inheritance is involved, but this aspect has not been investigated.

Morphologically, the pistillate capitula of the hybrid plants are identical to those of the desert broom maternal parent, but they were variable in size and reduced in length and diameter (Fig. 3). While the number of pistillate flowers per capitulum and capillary bristles per pistil in the hybrid were similar to those of the seed parent, the bristles of the pappus in the hybrid flowers were noticeably shorter (Table 1). In general, hybrid plants produced fewer capitula than the female parent. The hybrid plants produced smaller and lighter seeds than those of the desert broom plants (Table 1).

The size and shape of the leaves of the fully grown hybrid plants were intermediate between the two parental types at the same stage of maturity. The female desert broom parent had nonserrated, linearly shaped leaves, whereas the male coyote bush parent had obovate leaves with distinct serration and fivepointed edges (Fig. 4). The leaves of the hybrid plants were oblong, with or without pointed serration. Although the leaves of the hybrid plants were generally intermediate, those collected from various individual plants tended to vary in size.

The procumbent growth habit of the hybrid progeny, which was not readily apparent in young plants before transplanting into the field, became clearly evident after 1 to 2 years of growth (Fig. 2). Plant widths, measured in the spring of the sixth year of growth, ranged from 152 to $409 \mathrm{~cm}$, and plant heights ranged from 66 to $220 \mathrm{~cm}$ (Table 1). The mean width of the hybrid plants was $48 \mathrm{~cm}$ wider and the mean height $113 \mathrm{~cm}$ shorter than the comparable desert broom-type plants. The width : height ratios of the hybrid was nearly twice that of the desert broom-type plants ( 2.01 vs. 1.24 , respectively), thus characterizing the degree of procumbency of the hybrids. There was a considerable range in procumbency of the individual hybrid plants (width : height ratio range $=1.39$ to 3.34 ). Most of the hybrids, unlike desert broom, produced numerous branches at the base, which contribute to the compact appearance of the plants. The high degree of variation in height, width, width : height ratio, leaf shapes, branching habit, and

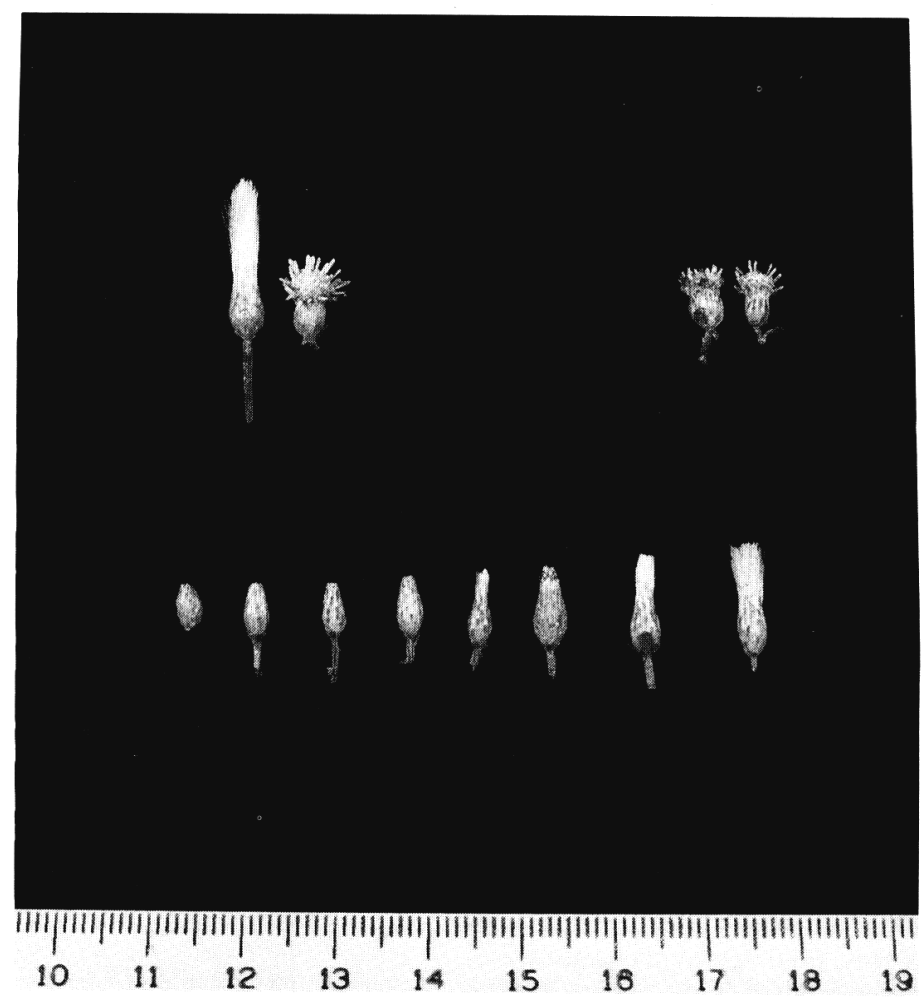

Fig. 3. Baccharis flowers: (upper left) pistillate and staminate capitula of desert broom (B. sarothroides); (upper right) staminate capitula of coyote bush (B. pilularis); and (bottom) range in size of pistillate capitula found on individual first-generation $\left(\mathrm{F}_{1}\right)$ plants of the $B$. sarothroides $\mathrm{x} B$. pilularis interspecific hybrid

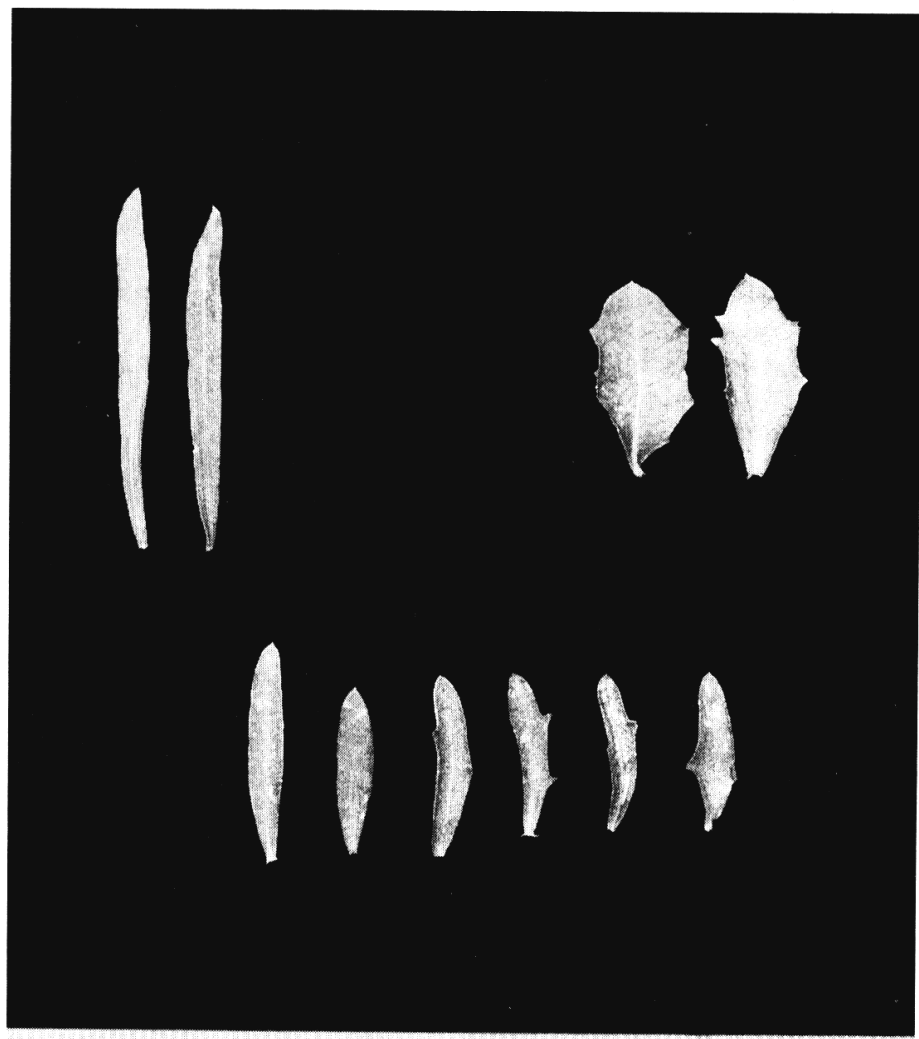

Fig. 4. Baccharis leaf morphology: (upper left) leaves of desert broom (B. sarothroides); (upper right) leaves of coyote bush (B. pilularis); and (bottom) leaves of the first-generation $\left(\mathrm{F}_{1}\right)$ plants of the $B$. sarothroides $\mathrm{x}$ B. pilularis interspecific hybrid. 
number of flowers per plant suggests a high level of genetic heterogeneity within the hybrid population.

In general, most capitula on pistillate plants of Baccharis species produce an excessive amount of pappus at maturity. The pappus on the hybrid plants is somewhat of a problem but less so than that of the pistillate desert broom plants. The number of pistillate florets in the capitula of the hybrid was less than the female parent $B$. sarothroides (30.7 vs. 44.1 ), and the bristle length of the hybrid's pappus tended to be shorter ( 8.8 vs. $11.7 \mathrm{~mm}$ ) (Table 1). The fewer capitula and pistillate florets produced by the hybrid plants also tend to minimize this constraint.

Although the hybrid plants have not been subjected to rigorous testing, they appear to have a high level of tolerance to various abiotic stresses, especially drought and low humidity. The plants survived summer heat of $45 \mathrm{C}$ without wilting, and also survived winter cold as low as $-10 \mathrm{C}$ in southern Arizona. The response of the hybrid plants to water stress, as determined by visual symptoms during 6 years of culture, was similar to that of the desert broom female parent. When grown without irrigation for 6 months in 1982, until the summer rains started, all hybrid plants grew normally and exhibited slight leaf-yellowing symptoms that also were evident within the desert broom population grown in the same field. Several selectedindividual hybrid plants, which were propagated by cuttings and established in several sites on the Univ. of Arizona campus in Tucson, also were as tolerant to water stress as the desert broom (Lee et al., 1984).

\section{SELECTION OF 'CENTENNIAL' BACCHARIS}

In July 1981, the 301 six-year-old hybrid plants were evaluated and rated for desirable landscaping characteristics. Plants were rated on a scale of A (favorable), B, C, D, and F (unfavorable) as an indication of their overall desirability andusefulness as a landscape plant. The primary rating factors were foliage color, growth habit, and degree of procumbency. Of these, 53 plants $(17.6 \%)$ were rated an A. The rest of the plants in the population were rated asfollows: $\mathrm{B}=17.9 \%, \mathrm{C}=32.9 \%, \mathrm{D}=26.2 \%$, and $\mathrm{F}=5.4 \%$. Plants classified as $\mathrm{F}$ usually were upright-growing types that resembled the desert broom female parent, although they exhibited some hybrid plant characteristics. Of the plants rated as A, $11(3.7 \%)$ were given an $\mathrm{A}+$, which indicated superior landscaping characteristics. Several of these plants were propagated by cuttings for further evaluation.

After evaluation, one plant was selected as having the best combination of desirable horticultural characteristics (Fig. 5). The selection was named 'Centennial' and released by the Univ. of Arizona Agricultural Expt. Station for propagation and use by the general public (Lee et al., 1984; Thompson, 1985). The potential value of 'Centennial' as an urban desert landscape plant soon was recognized by the media (Sunset, 1984).

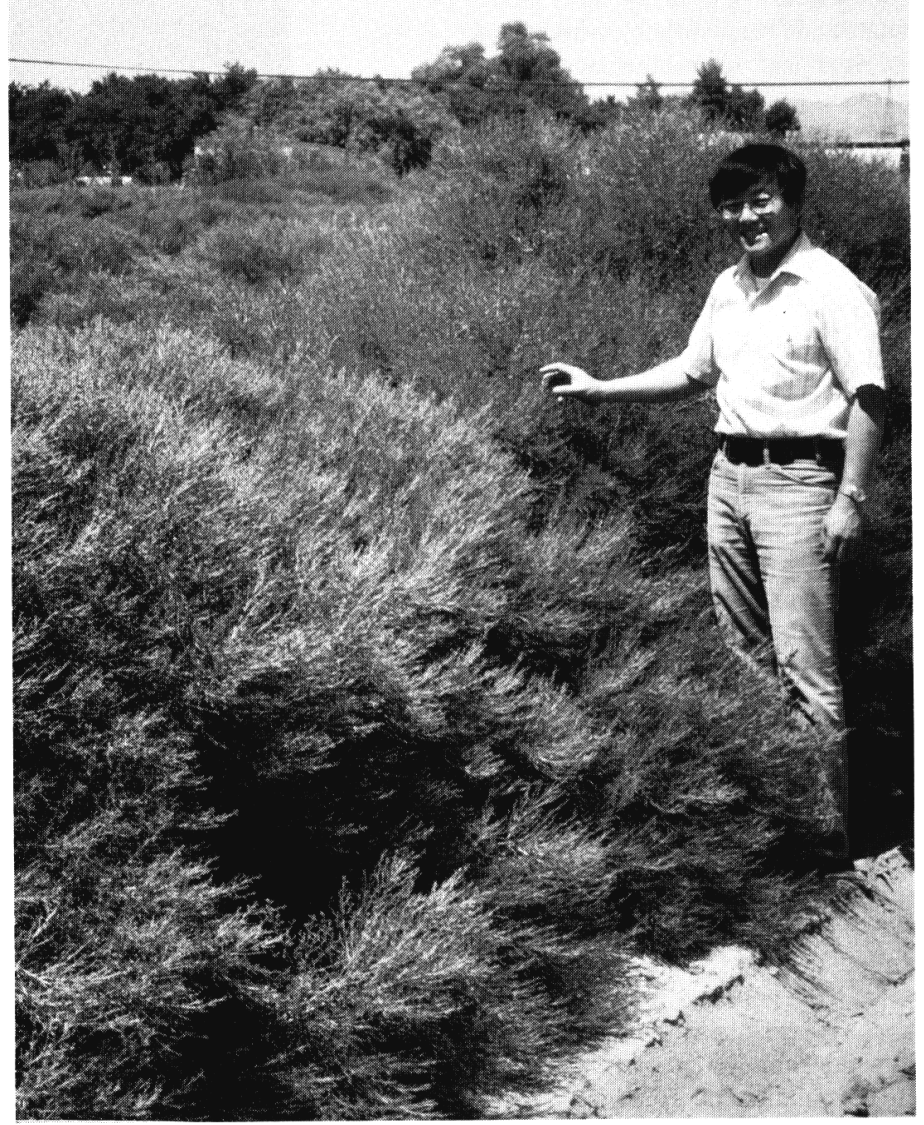

Fig. 5. Selected plant (to left of C.W. Lee) within a 6-year-old population of the Baccharis sarothroides $\mathrm{x}$ B. pilularis interspecific hybrid, which subsequently was named andreleased as 'Centennial' Note sister hybrid plant with more upright growth habit behind C.W. Lee.

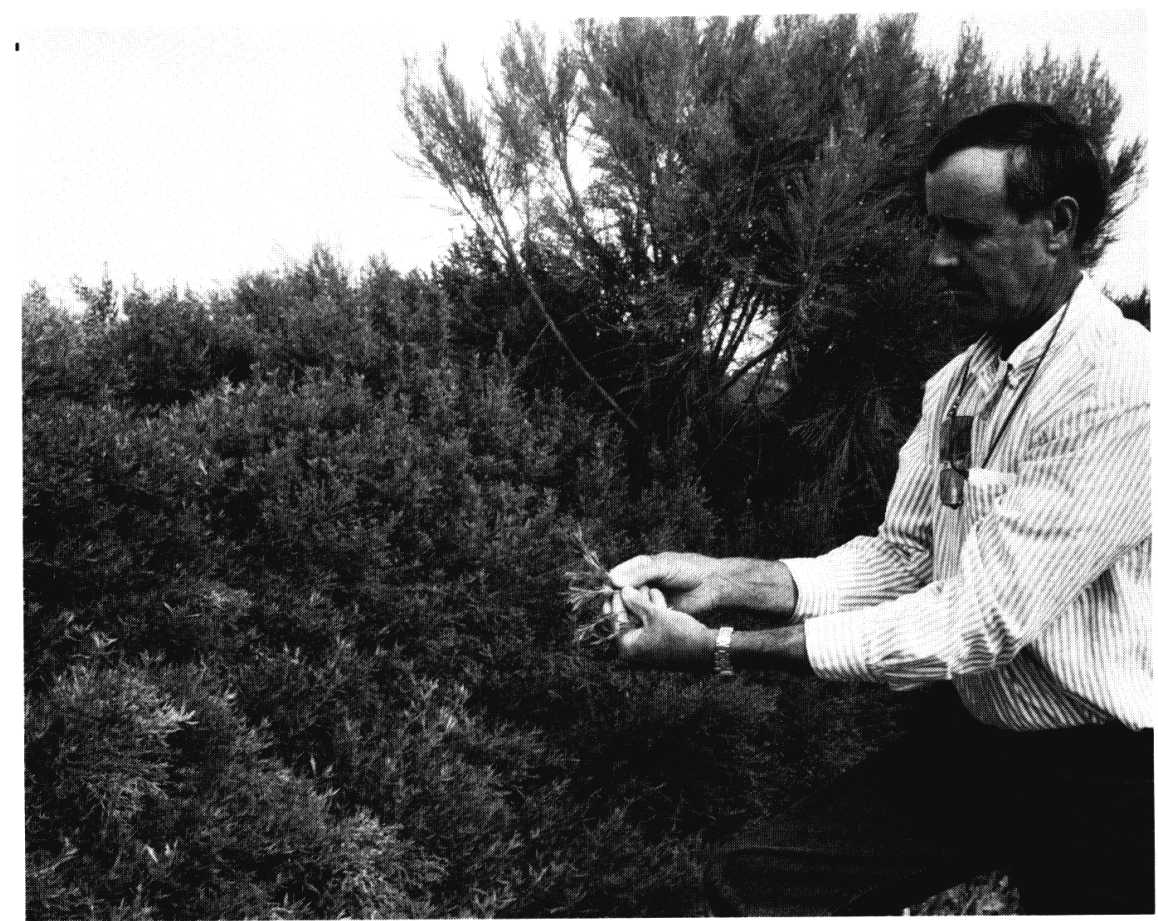

Fig. 6. (left) Mature second-generation, backcross plants from a chance cross of 'Centennial' baccharis $\mathrm{x}$ desert broom (Baccharis sarothroides). Note the erect growth habit of the nonhybrid desert broom plant in the background. Coauthor Gass is holding and comparing (left) a single branch of the desert broom parent with (right) two branches of the new second-generation hybrid. 
In 1984, several 'Centennial' plants were planted in the Mountain States Wholesale Nursery demonstration garden for evaluation. During the next 3 to 4 years, performance of the plants was observed by landscape architects, and interest in 'Centennial' continued to build for its desirability and suitability for landscape purposes. Because of this interest, cuttings were made on several occasions to test methods of propagation. 'Centennial' was relatively easy to propagate by rooting stem cuttings and also was essentially free of pests and diseases.

The cultivar met with widespread acceptance for landscaping golf courses and other large-scale projects in the desert southwestern United States, especially when slopes required perennial vegetation. Eric Johnson, a landscape designer and consultant in the Palm Springs, Calif., area, served as a champion for 'Centennial' in landscaping golf courses and streetscapes. Notice of his acceptance and work gave impetus for further use by others. 'Centennial' now is recommended for planting in Arizona (Arizona Municipal Water Users Assn., 1991) and has been and continues to be a major item propagated and distributed by the Mountain States Wholesale Nursery. Because the cultivar was not protected by a plant patent, it also is propagated widely by other nurseries.

\section{DEVELOPMENT OF SECOND- GENERATION BACCHARIS HYBRIDS}

When the original interspecific hybrid was contemplated and made in 1975, there was little expectation that something as desirable as 'Centennial' could be selected out of the first-generation progeny. The juvenile hybrid plants gave little indication of the desirable degree of prostrate growth manifested in the more mature plants. During the evaluation of 'Centennial' in the commercial nursery, mature plant specimens obviously exhibited a mounding growth habit that took them out of the category of a low groundcover. A set of specifications for a new, improved baccharis hybrid cultivar was formulated, which, if attainable, would provide an even superior landscape plant for the arid southwest deserts. Disease resistance and low growth habit were of prime importance. Other desired characteristics were high levels of heat, cold, and drought tolerance, which are strongly represented in 'Centennial' and its parent, the desert broom. While the reduced production of pappus on 'Centennial' stands out in contrast to the native desert broom pistillate plants, elimination of pappus production, or a marked reduction over that of 'Centennial', was considered to be an important attribute in a new cultivar.

During the propagation of 'Centennial' at the Mountain States Wholesale Nursery, we noted that some viable seeds were produced on the plants. Because no coyote bush plants were in the vicinity, pollen must have originated from staminate plants of desert broom, which grow profusely in the surrounding area. $\mathrm{Ca}$ pitula were collected, and seeds that appeared to be viable were saved and planted in the greenhouse. About 2800 seedlings were transplanted into small pots, and then moved into 3.8-liter cans to observe their growth habits. The seedling plants displayed a wide range of leaf types. As the plants matured, most tended to exhibit either the oblong, serrated leaf shape of 'Centennial' or the smooth, linear shape of the desert broom parent. Because the primary selection criterion was for low procumbent growth habit, leaf type was essentially ignored in the process of eliminating or roguing out the less desirable plants. A final selection was necessitated by pressure for production space in the nursery when the plants were about 1 year old. Twenty seedlings were selected based on low growth habit and fullness of branching structure and were planted in a soil bed for further evaluation (Fig. 6)
The first blooming season of the 20 selected hybrids revealed the presence of several staminate plants, which presented pros and cons to consider in the selection process. One consideration was introgression or infusion of genes from the poorly adapted coyote bush (B. pilularis) parent into the arid environment where these baccharis hybrids would be grown. Because some genetic segregation for sex expression was evident in the second-generation hybrid seedlings, the increased frequency of staminate-flowering hybrid plants could increase the frequency of less well-adapted genes from $B$. pilularis. This increase could be mediated by wind pollination of pistillate plants of the native population of desert broom or those of 'Centennial' by the staminateflowering selection. Because most of the po-

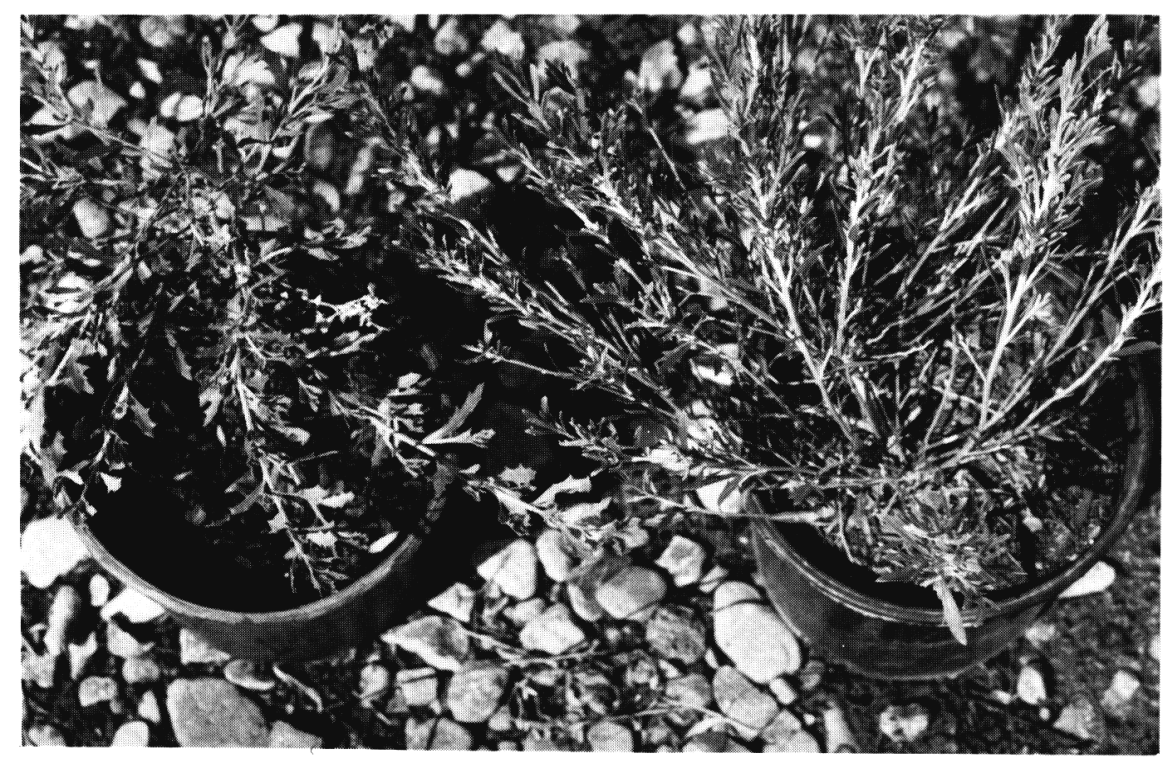

Fig. 7. Twelve-month-old plants of (left) 'Centennial' baccharis and (right) a selected staminate, secondgeneration hybrid baccharis plant of 'Thompson'. Note the differences in leaf morphology and the slightly more erect juvenile growth habit of 'Thompson' at this stage of maturity.

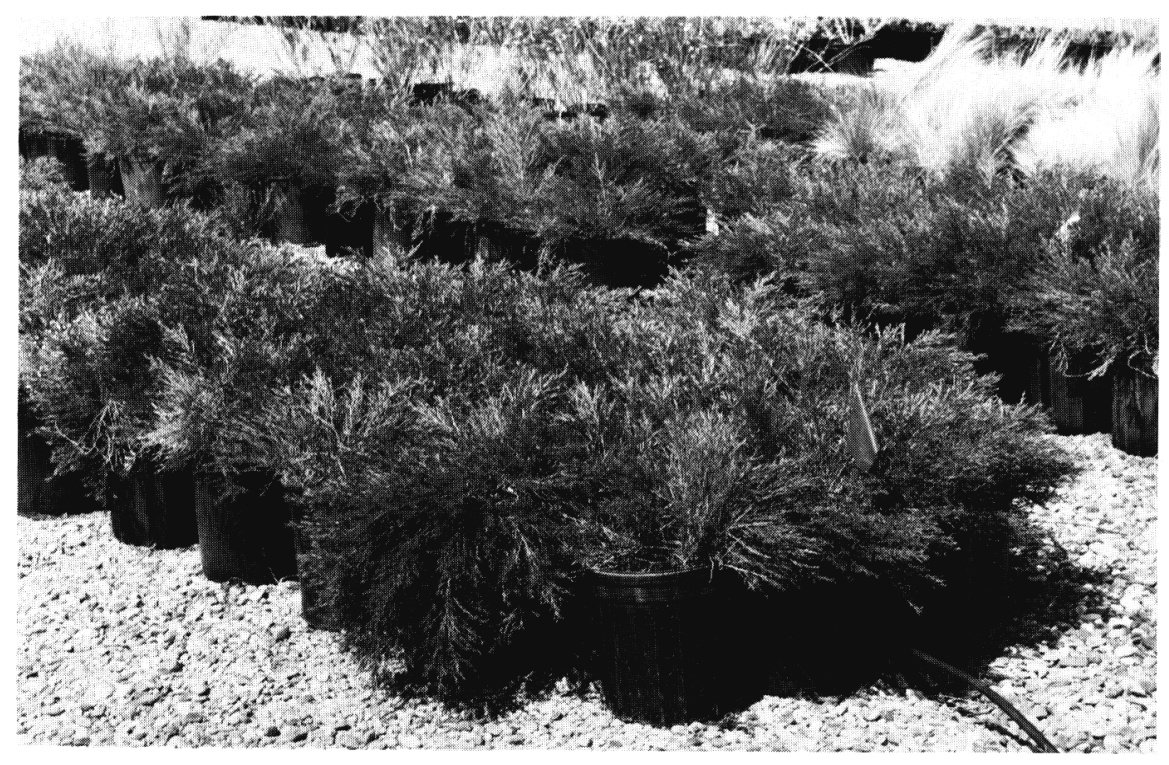

Fig. 8. Two-year-old, mother-block, increase plants of 'Thompson', a second-generation baccharis interspecific hybrid, growing in 19-liter containers in the nursery. 
tential impact likely would be restricted to landscaped areas, it likely would not have much consequence throughout the ecological range of the desert broom $B$. sarothroides. Additionally, if a staminate second-generation hybrid were widely planted, there might be some possibility of aggravating allergy sufferers through the increased generation of pollen. Again, we do not consider this potential negative impact as a serious problem because the pollen production of a cultivated hybrid would be minimal compared to the current pollen production from staminate plants of the native desert broom in any given area.

The positive benefits from selecting a staminate flowering, second-generation, baccharis hybrid appears to outweigh any problems. Propagation of an all-staminate hybrid would eliminate the dispersion of unwanted seedlings, except for potentially creating backcross hybrid progeny as previously discussed. The most positive aspect would be eliminating production and dispersal of unwanted pappus from the maturing capitula. Although 'Centennial' is less objectionable than the desert broom, in some years, it will flower heavily and produce a significant amount of pappus from the pistillate capitula. Any reduction in this nuisance by using an all-staminate hybrid plant would be of value.

After growing the selections in field plots for 3 years and considering these alternatives, the Mountain States Wholesale Nursery de- cided to select and propagate the superior staminate, second-generation hybrid plant, which has a desirable degree of procumbency and vigor. This plant also has a leaf shape that is intermediate between 'Centennial' and the male backcross parent, desert broom (Fig. 7). The new cultivar was named 'Thompson'. It is in the process of being patented and increased and is expected to be available for sale to the public in 1996 (Fig. 8).

The new introduction will probably compete directly with 'Centennial' in landscape applications. The primary advantage of 'Thompson' most likely will be its lack of pappus and seed production. The ultimate plant size and character of the two hybrids are similar, as are the color and texture of the foliage. Because it has a higher frequency of genes derived from its desert broom parent ( 0.75 vs. 0.50) 'Thompson' may surpass 'Centennial' in its tolerance to environmental stresses (such as heat, cold, and drought) and diseases. Only time will determine the relative merits of these two useful desert landscape plants.

Additional improvements likely can be made with further breeding and selection. Undoubtedly, improvements could be made in procumbency and increased leaf surface by backcrossing the new second-generation hybrids once again to the coyote bush or to 'Centennial'. In any event, these new baccharis hybrids have an increasingly important role to play in future arid-land landscaping.

\section{Literature Cited}

Arizona Municipal Water Users Assn. 1991. Xeriscape gardens: Plants for the desert southwest. 3rd ed. Arizona Municipal Water Users Assn., Phoenix.

Duffield, M.R. and W.D. Jones. 1981. Plants for dry climates: How to select, grow and enjoy. H.P. Books, Tucson, Ariz.

Kearney, T.H. and R.H. Peebles. 1960. Arizona flora. 2nd ed. Univ. of California Press, Berkeley.

Lee, C.W., A.E. Thompson, W.D. Jones, and L. Hogan. 1984. 'Centennial' baccharis interspecific hybrid. HortScience 19:903.

Munz, P.A. 1974. A flora of southern California. Univ. of Southern California Press, Los Angeles.

Natural Vegetation Committee, ArizonaChapter of Soil Conservation Society of America. 1973. Landscaping with native Arizona plants. Univ. of Arizona Press, Tucson.

Sacamano, C.M. and W.D. Jones. 1975. Native trees and shrubs for landscape use in the desert southwest. Univ. of Arizona College Agr. Coop. Ext. Serv. Bul. A 82.

Sunset. 1984. A brand-new variety may eliminate the problem of Bacchan's decline. Sunset 172(6):237.

Thompson, A.E. 1985. New native plants for the arid southwest. Econ. Bot. 39: 436-453.

Thompson, A.E., W.D. Jones, and L. Hogan. 1976. Breeding and selection of native landscape plant materials for arid regions. HortScience 11:330. (Abstr.) 